\title{
USING MIND MAPS IN TEACHING COMPUTER NETWORKS
}

\section{Son̆a NERADOVÁ-Josef HORÁLEK}

Abstract: This article describes using of mind maps for teaching Computer networks on FEI of University Pardubice.

Key words: mind map, computer networks, pyramid of learning, laboratory task.

\section{VYUŽITÍ MYŠLENKOVÝCH MAP VE VÝUCE POČÍTAČOVÝCH SÍTÍ}

Resumé: Článek popisuje využití myšlenkových map ve výuce předmětu Počítačové sítě na Fakultě elektrotechniky a informatiky Univerzity Pardubice.

Kličcová slova: myšlenková mapa, počítačové sítě, pyramida učení, laboratorní úlohy

\section{1 Úvod}

Výuka předmětu počítačové sítě na Fakultě elektrotechniky a informatiky Univerzity Pardubice je standardně rozdělena na přednášky a laboratorní cvičení. Rozsáhlá problematika oblasti počítačových sítí, je na FEI UPCE rozdělena do čtyř semestrů $\mathrm{v}$ předmětech IPS1 až IPS4 , které na sebe postupně navazují. Je tak vytvářena pyramida znalostí, $v$ jejíchž základech stojí obecné principy fungování počítačových sítí TCP/IP, na něž pak navazují dvě nejvýznamnější oblasti, a to principy směrování a préepínání. Znalosti získané $\mathrm{v}$ těchto třech oblastech pak student využívá $\mathrm{v}$ posledním bloku, zaměřeném na technologie rozsáhlých sítí typu WAN. [3]

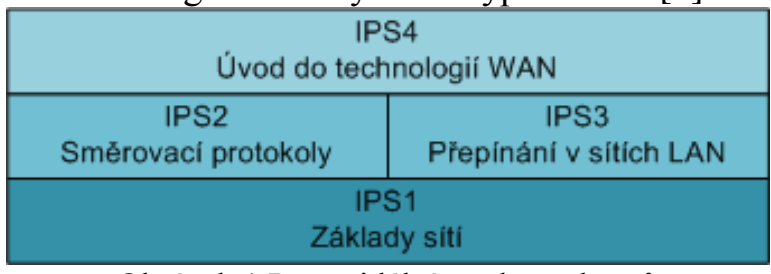

Obrázek 1 Pyramidální struktura kurzů

Významným specifikem těchto předmětů je vysoký důraz, kladený na domácí př́pravu studentů. Pro úspěšné absolvování těchto předmětů je student povinen pravidelně průběžně ověřovat své znalosti pomocí elektronických testů. Tento postup je nezbytný proto, že samotné semináře jsou $\mathrm{z}$ významné části naplněny samostatnou odbornou činností formou laboratorních cvičení. Jelikož studenti při této činnosti využívají reálná sítová zařízení (směrovače, přepínače, strukturovanou kabeláž atd.), jsou teoretické znalosti získané na přednáškách a $\quad z \quad$ e-learningových kurzů nezbytností. Dalším významným prvkem je reálné časové omezení (doba cvičení) pro úspěšnou realizaci aktuálního zadání.

\section{Pyramida učení}

Jak již bylo zmíněno výše, je při výuce př̀edmětů $\mathrm{z}$ oblasti počítačových sítí využiváno několik výukových metod. O jejich efektivitě vypovídá tzv. pyramida učení, která popisuje účinek použivání jednotlivých výukových metod. Základní myšlenka této pyramidy zní: Člověk (student) získává tím více informací a schopností, čím je aktivněji zapojen do procesu výuky. Procenta zapamatování uvedená u jednotlivých výukových metod jsou proměnlivá, jelikož efekt použití každé $\mathrm{z}$ nich závisí na mnoha dalších faktorech: jako jsou motivace studentů, únava studenta, jejich předchozí zkušenost, atd. [1]

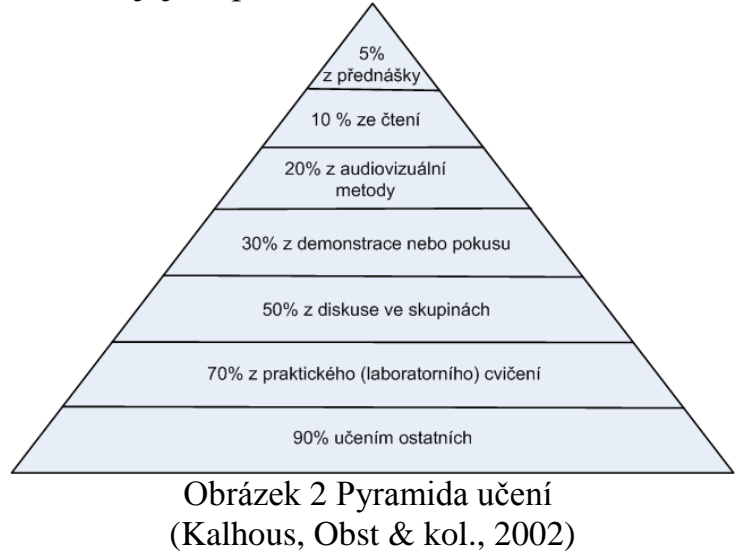

Pro výuku počítačových sítí, vedených výše popsaným způsobem, se vyučující pokusili navýšit procenta zapamatování z laboratorního cvičení zařazením myšlenkových map do výuky. Tato metoda byla testována u jedné strukturně standardní skupiny studentů. Bylo postupováno následujícím způsobem: studenti byli seznámeni se samotným pojmem „myšlenková mapa“. Myšlenkové mapy jsou grafickým vyjádřením základních částí řešeného problému, jednotlivých dílčích složek a jejích vzájemných souvislostí [2]. 
Hlavní části jsou zakreslovány pomocí popsaných obrazců a základní myšlenka popisující hlavní části je vepsána do obrazce. Spojení - linka vyjadřující souvislost mezi hlavními částmi nebo dílčími složkami je zakreslena jako čára. Každá linka by měla být označena jednoduchým klíčovým slovem nebo slovním spojením. Tento postup a grafické znázornění studovaného problému umožňuje lepší uvědomění si a pochopení vzájemných vazeb řešeného úkolu.

Studenti dostali s týdenním předstihem náplň cvičení společně s tzv. slepou myšlenkovou mapou. Slepé myšlenkové mapy obsahovaly jen některé části určitého zadání. Povinností studentů bylo doplnit chybějící části. Postupně, tak jak se zvyšovaly předpokládané znalosti studentů, byly slepé mapy, které studenti dostávali společně se zadáním, stále jednodušší - studenti tak museli doplňovat více údajů. Na začátku každého cvičení pak byly mapy vytvořené studenty společně vyhodnoceny. $\mathrm{V}$ př́padě potřeby byly myšlenkové mapy doplněny či opraveny o chybějící údaje nebo vazby. Na posledním cvičení pak studenti vytvořili vlastní mapy pro zadanou problematiku. Významným faktorem při doplňování slepých myšlenkových map byla skutečnost, že studenti při práci nepoužívali žádný specializovaný software, mapy byly jednoduše kresleny na papír. Tento fakt nebyl způsoben nedostupností vhodného software - autoři tím sledovali sekundární cíl, kterým bylo zvýšení efektivnosti zapamatování si vlastností a vazeb daného tématu vytvářením grafických modelů, kterým takto vytvořená myšlenková mapa samozřejmě je.

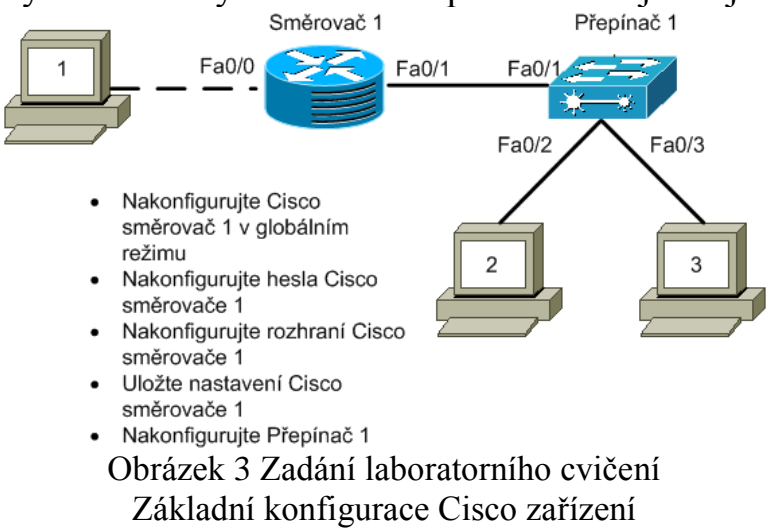

$\mathrm{Na}$ obrázku 3 je uvedeno schéma zadání ukázkového laboratorního cvičení. Konkrétně se jedná o základní konfigurace vybraných Cisco zařízení, obsahující pět základních cílů. Pro správné splnění těchto cílů je nutné uvést správnou konfigurací každého ze zařízení. Toto zdánlivě jednoduché zadání skrývá množství již zažitých znalostí a dovedností. Jako př́iklad lze uvést výpočty IP adres podsítí, znalost práce s operačním systémem koncových stanic a jednotlivých prvků či znalost metod pro ověření vzájemné konektivity včetně praktického využití nejvhodnější metody.

Pro představu a podtržení významu myšlenkových map lze uvést malý příklad, kdy pouhý výpis konfigurace Směrovače $1 \mathrm{z}$ našeho př́ikladu obsahuje téměř 40 řádkủ. Je zřejmé, že zapamatovat si všechny potřebné př́kazy a jejich strukturu není jednoduchý úkol, jeho splnění bezpodmínečně vyžaduje neustálé procvičování. Právě struktura myšlenkových map upevňuje znalost př́kazů a podstatných vazeb a souvislostí. V programu výuky počítačových sítí na FEI UPCE je součástí oveř̌ování praktických vědomostí a dovedností studentů realizace zadání pomocí vhodného simulačního programu. Vyhodnocení je pak automatizováno a provedeno simulačním programem, umožňujícím kontrolu správnosti použití př́íkazů a kompletní funkčnosti daného zapojení. Úspěšnost je pak vyhodnocována $\mathrm{v}$ procentech. Na obrázku 4 uvádíme příklad slepé myšlenkové mapy vztažené k zadání na obrázku 3 .

\section{Závěr}

Schopnost studenta diagnostikovat potíže $\mathrm{s}$ adresováním sítových adres a opravit je, to je jedna $\mathrm{z}$ věcí, která ho $\mathrm{v}$ praxi často čeká. Právě nejčastějším problémem pro studenty počítačových sítí je vytvoření adresného schématu sítových adres, ověřování konektivity zařízení a řešení potíží. Některé úlohy jsou prrímo obsahově zaměřené na řešení potíží, které se $\mathrm{v}$ počítačových sítí mohou $\mathrm{v}$ určité konfiguraci zařízení vyskytnout. Proto jsou výpočet a přidělení sít'ových adres součástí většiny laboratorních úloh ve všech předmětech počítačových sítí. Pokud tuto oblast student nezvládne, tak vzniká chyba, která se přenáší do řešení celého zadání a ovlivňuje získávání navazujících znalostí a dovedností. Výsledkem pak je podstatně nižší úspěšnost nejen u vyřešení zadaných úloh, ale u praktických testů.

Použitím myšlenkových map u jedné strukturně standardní skupiny studentů, došlo poměrně $\mathrm{k}$ výraznému posunu $\mathrm{v}$ úspěšnosti výpočtu sít'ových adres což, ovlivnilo i celkový výsledek u každého studenta této skupiny a to v průměru o $8 \%$. 


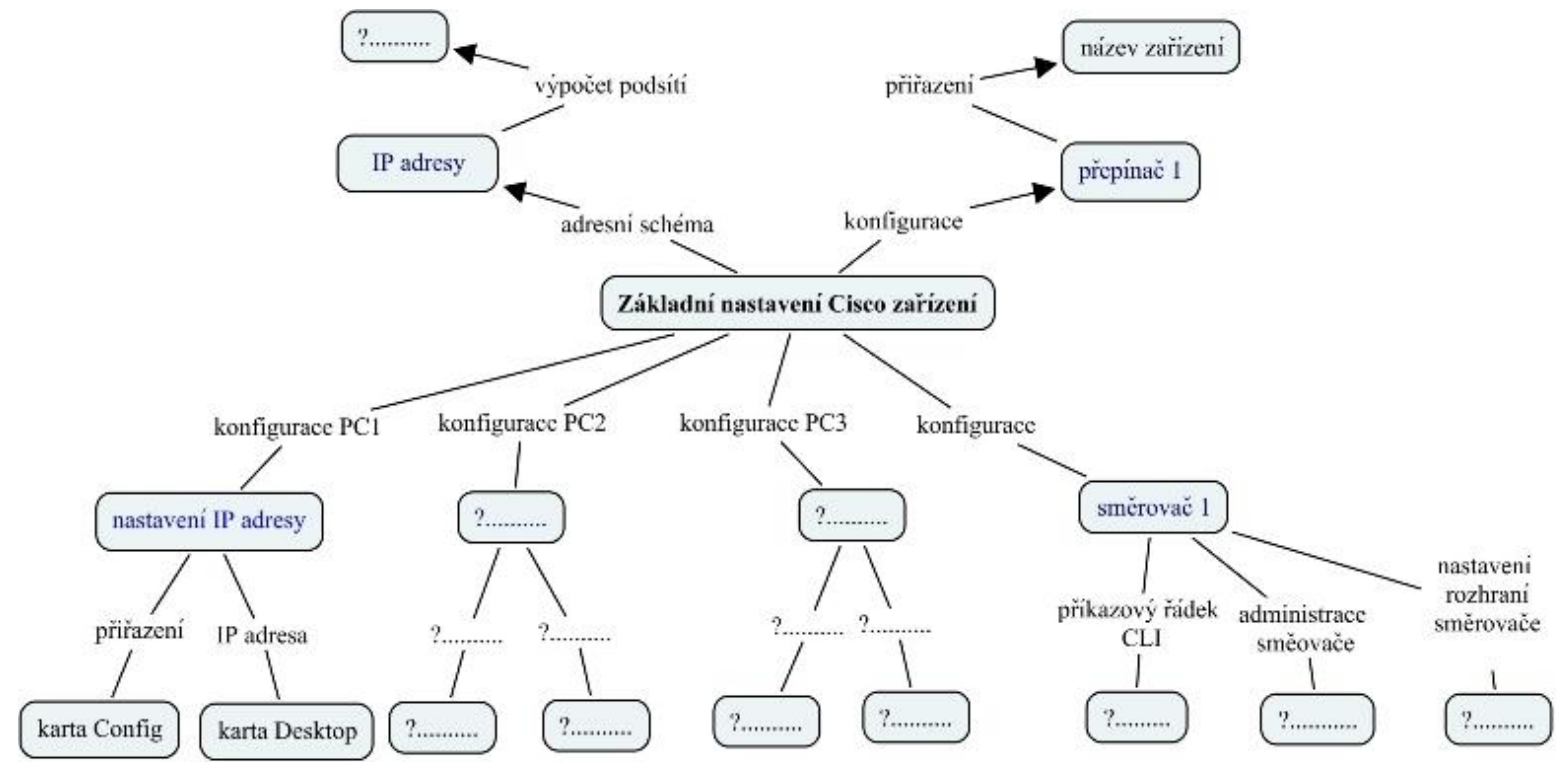

Obrázek 4 Slepá myšlenková mapa Zadání laboratorního cvičení - Základní konfigurace Cisco zařízení

\section{Literatura}

[1] KALHOUS, Z.; OBST, O. Školní didaktika. 1. Praha : Portál, 2002. 447 s. ISBN 978-807367-571-4.

[2] BUZAN, Tony. Mentální mapování. Praha : Portál, 2007. 165 s. ISBN 978-80-7367-200-3.

[3] LAMMLE, T. CCNA : Výukový průvodce př́pravou na zkoušku 640-802. 1. Brno : COMPUTER PRESS , 2010 . 928 s. ISBN 97880-251-2359-1.
Mgr. Josef Horálek

Katedra softwarových technologií

Fakulta elektrotechniky a informatiky UPCE

Studentská 95

53210 Pardubice 2, ČR

Tel: +420 466037004

E-mail: josef.horalek@upce.cz

Ing. Soňa Neradová

Katedra softwarových technologií

Fakulta elektrotechniky a informatiky UPCE http://www.upce.cz/fei/kst.html 